\title{
Housing access and affordability in rural England: tackling inequalities through upstream reform or downstream intervention?
}

\author{
Nick Gallent, Iqbal Hamiduddin, John Kelsey and Phoebe Stirling
}

There has been longstanding policy and academic interest in the distribution of housing resources in rural amenity areas, both across Europe and the US. A combination of development constraint for reasons of amenity protection, low wages in seasonal employment and market intrusion by more affluent households - who consume rural housing for the investment or amenity opportunities it offers - generate housing access and affordability difficulties for some existing residents. In response, residents' groups and public planners have sometimes sought to prioritise 'local needs', restricting the occupancy of new housing to key workers or others deemed to be 'local'. Drawing on examples from amenity areas in England, this paper argues that these 'downstream' interventions are often rendered ineffective by the upstream and structural drivers of housing access inequality: by patterns of private property ownership (framing competition between 'domestic property classes'), by economic restructuring (reflected in wage and wealth differentials) and by the priorities of rural planning policy and the amenity/investment motives of market entrants. The likely impacts of downstream local planning interventions - aiming to widen access to housing at this lowest level - is examined, drawing on general theory, past evidence, and the authors' own work in Cornwall. The conclusion reached is that only through upstream action - a combination of tax and land reform that addresses patterns of housing consumption 'at source' and create opportunities for communities to take control of land for community use - will it be possible to deliver greater fairness in rural housing access.

Rural housing / England / domestic property classes / planning intervention / tax and land reform

\section{Introduction}

Housing affordability is an important social and economic challenge for many advanced economies. Rising mortgage and rent costs are locking younger generations out of housing markets, causing financial stress - on individuals and national economies - and rising anxiety (Gallent, 2019a). Rolnik (2013) contends that the treatment of housing as a financial asset, rather than as a fundamental right, is at the root of the housing crises that are today manifest in many parts of the world. But financialisation is only one of many drivers conspiring to deprive people of access to the decent homes they need. A combination of factors, that varies from place to place, is responsible for housing stress: these include inadequate levels of new supply relative to the full spectrum of demand (linked to the practices of private enterprise and planning restriction; Bowie, 2017), historically low interest rates (and rising direct investment demand; Mulheirn, 2019), the substitution of publicly-financed social welfare with asset-based welfare (with implications for how housing is consumed; Rossi, 2017) and a withdrawal from public housing programmes (Tunstall, 2015).

Urban areas have been the primary focus for many studies. This is perhaps not surprising given the concentration of population in cities, with their many social and environmental challenges. The UK shares this urban focus. But inequalities in housing wealth are not confined to London, despite its more obvious connectivity to global flows of people and capital. They are felt in both prosperous and in 'left behind' places and are present in many parts of the countryside. Rural amenity areas around the globe have seen an influx of seasonal and retired residents over recent decades. This has been reported and analysed in the US (Marcouiller et al, 2011), Australia (Argent et al, 2014) and many 
different parts of Europe (Gallent et al, 2003; Paris, 2010). Amenity migration is, in general terms, accused of driving rural gentrification and perpetuating social exclusion (Lekies et al, 2015). More specifically, it underpins social change by acting on land values and rents, bidding up house prices, especially where the priority of land-use planning is the protection of that amenity - village character, open countryside or attractive coastlines - which attracts investors and supports a tourism economy.

In terms of housing affordability in England, the mismatch between lowest quartile local earnings and lowest quartile house prices is greatest, on average, across rural areas (see Gallent, 2019b) and most acute in rural amenity areas - especially in small attractive villages across the south of the country. These ratios are, however, most stretched in the most prestigious London postcodes and invariably reflect a divide between the wealth and wages of 'local residents' (whose earnings are reported in the data) and the 'imported' wealth of market entrants (whose presence pushes up land and property prices). This is true in London - or indeed in Sydney, New York, Paris or Hong Kong - where members of the global economic elite choose to park their wealth, but also in a great many rural and coastal areas where 'more prosperous groups' seek the amenity and investment advantages of a home in the accessible countryside. Global and domestic elites recognise a shared truth: that property, and the land it sits on, is the best parking place for surplus capital. It is therefore property, and uneven competition between 'property classes' (Saunders, 1984), that provides the starting point for thinking about housing inequality, whether in urban or rural areas.

The purpose of this paper is to examine the structural causes of housing access and affordability difficulties in rural England and to compare the operation of lowest level ('downstream') planning interventions with potential 'upstream' reforms, arriving at an assessment of different approaches to engineering alternative housing outcomes. The case studies presented-our own and drawn from the work of others - are used to illustrate the challenges of reshaping housing outcomes in rural amenity areas. The first part of the paper examines three levels at which those outcomes might be explained and described: upstream, mid-level and lowest level. Upstream, the advantages brought by the conditioning of tenure and by socio-economic class produce different class (associational) interests and expectations from property (and therefore also from market interventions). At the mid-level, the historic restructuring of economic activity has resulted in a shift from rural production to rural consumption, rising urban/rural wealth differentials and housing market intrusion by more prosperous groups. At the lowest level, attention is focussed on local market dynamics and intervention limited to what is operable by local authorities. Thus planning is leveraged towards addressing the immediate competition between different property classes - for example by restricting occupancy of new housing to local residents - rather than efforts being made to enact systemic change upstream.

The second part explores lowest-level market intervention and its consequences, drawing on theory, past experience and the authors' own research. The impacts of local planning correctives is illustrated using past evidence from the Lake District, and more recent evidence from Cornwall. The aim of occupancy restrictions is firstly to give advantage to one domestic property class (lower income and lower wealth groups) over another (more prosperous groups moving into an area) and secondly to decelerate the flow of mobile capital into a market area, thus slowing the rate of house price inflation. But they operate in the new build segment of the housing market and can therefore result in reduced development activity alongside intensified demand for housing (and rising prices) in the existing housing stock. The aim of not advancing comprehensive supply solutions is to avoid the disruption and destruction of local amenity and therefore protect the tourist economy: more targeted supply, for local need, requires public and community control of land. Without that control, the permissioning 
of market development and the attempt to then restrict the occupancy of private housing, might be viewed as a second-best solution, but one that generates a number of tensions.

The third part of the paper considers the options for upstream reform, centred on the tax treatment of housing and the transfer of developable land from private ownership. It is proposed that tax reform could play in important role in reshaping patterns of housing consumption in rural areas whilst land reform will facilitate community-led housing for local need, providing a means of resourcing local projects and targeting new supply at full-time residents. Together, these measures would result in a more just distribution of housing resource whilst avoiding the unintended consequences of downstream occupancy restrictions, which focus unfettered demand in the second-hand market and discourage new housing supply.

\section{Part I: Framing the rural housing challenge}

The analysis of rural housing outcomes often begins with the study of local market dynamics: who is being locked out and by whom. But these dynamics are expressions of upstream structures and processes. We propose that a fundamental upstream structure (property) drives mid-stream process, resulting in the lower-stream outcomes that become a focus for planning restriction.

\section{a) Upstream - property and class}

Many conceptual analyses of housing market outcomes build on Max Weber's notion of 'life chances in the market' being determined by social class (Saunders, 1978: 235), thereafter developed in Saunders' (1984) conceptualisation of 'domestic property classes'. Private property provides a framework for market action, motivated by wealth accumulation. Market outcomes downstream who is locked out and by whom - are determined by the property histories of different classes, and often by the intergenerational transfer of property wealth. This means that domestic property (i.e. housing) is a channel of class reproduction, providing a framework in which advantage is continually sought. Household income is an inevitable determinant of housing market advantage under capitalism. But it is property (and tenure divisions) rather than income poverty that fix outcomes over time and across generations. Saunders (1984) underscores this importance of tenure and the primacy of domestic property ownership in the 'structuration of class' (p. 202). He argued that owner occupiers constitute a distinct domestic property class, advantaged relative to public or private renters - or occupants of tied housing - by the releasable (and potentially mobile) equity they have accumulated through asset ownership. Within a bounded market, a simple division exists between advantaged owners and disadvantaged non-owners. But where there are market entrants, a more complex pattern of advantage and disadvantage emerges, with the scales of advantage often tilted towards those entrants. These may be investors, motivated to enter a new market by their wealth advantage and the expectation of capital appreciation. But it is generally true that a mix of amenity and investment goals (either capital return or rent revenue) motivates housing consumption. Across rural areas, private entrants include those relocating to retire, those commuting from rural locations back to urban jobs, lifestyle downshifters, second home buyers largely motivated by amenity goals, and holiday let investors looking to capture rental income (but who often know an area well by virtue of already residing locally). Gallent et al (2005) draw attention to the presence of these different types of market entrant across European rural areas, noting also the division between salaried incomers (or former salaried retirees) and local wage labour - a division previously noted by Pahl (1975) and one that reinforces market power asymmetries.

The extent to which market entry accentuates existing disadvantage will depend on the housing (tenure) circumstances of existing residents. The injection of new capital, pushing up house-prices, 
will make it more difficult for local homeowners to 'trade up' through the market or for households aspiring to leave the private rental sector from doing so. These outcomes are common to urban areas (London's housing crisis is marked by rising rents and falling levels of home-ownership) and to rural areas, where lower income groups - lacking a family history of homeownership - are confined to a shrinking social rented sector. Market impacts will always be greater where there is a concentration of people trying to become home-owners for the first time or where rising house prices are reflected in upward rent levels. Carrying the analysis beyond the owner / non-owner dichotomy, a number of researchers draw attention to the life-stage, family history and socio-economic class divisions that further complicate domestic property classes and produce 'consumption cleavages' within rural housing markets (see Pahl, 1966; Ambrose, 1974; and Dunn et al, 1981). Although these divisions are further complicated by the 'totality of social relations' implicated in housing consumption and production (Ball, 1986), Saunders' perspective is important here as it draws attention to inequalities in wealth and income, and the related property histories, that are critical to the patterning of housing market outcomes in rural areas. Competition between these classes is nevertheless, a subcomponent of a wider system of production and consumption.

Mark Shucksmith drew much of this work together in his studies of housing access in the Lake District (1981; 1990a) and subsequent reflections on market dynamics and social class (1990b). He observed that 'low income and low wealth groups' were invariably outcompeted by 'more prosperous groups' (ibid, 225) but that neither were homogenous groups. The most disadvantaged of the former tended to be childless singles and couples, who not only struggled to pay private rents and purchase property, but also found it difficult to access social housing (which was being sold off to sitting tenants, under the 'right to buy', and was anyway more likely to be allocated to households with children). Scales of advantage were observed amongst the more prosperous groups: income-poor owner-occupiers enjoyed a more stable existence but could struggle to maintain their property. Higher-income owneroccupiers, on the other hand, shared similar advantages (and 'associational interests' - Milbourne, 2006) with market entrants (moving in for retirement, second-home purchase or for life-style reasons - and then commuting back to city jobs), forming a more discrete property-owning class, which has since displayed shared class interest.

b) Mid-level - economic restructuring, counter-urbanisation and rural planning

Relative to this higher framing, structural processes that are specific to rural areas play a role in establishing the conditions (including the relative rent gap) that draw 'more prosperous' domestic property classes to rural areas. The first of these is economic restructuring, reflected in wage differentials between rural and urban workers. The second, linked to the switch from rural production to consumption, is the changing priorities of rural planning during the second half of the twentieth century (Satsangi et al, 2010).

The story of rural restructuring is a long one and cannot be fully recounted here. The industrial revolution caused the locus of economic production in the UK to shift and resulted in an urbanisation of people and capital: cities grew and rural areas shed population. As well as an economic shift away from primary industry to value-added activities, from the nineteenth century onwards the UK imported more of its food from overseas producers. Domestic farming quickly modernised, mechanised and needed fewer workers. By the end of the Second World War, four-fifths of the UK's population was concentrated in towns and cities (Lawton, 1973: 195). International competition in the farming sector drove down earnings. The reduced importance of farming as an employment sector had profound impacts on rural society (Martin, 1962). 
In the second half of the twentieth century, the UK's economy restructured again: this time, away from manufacturing and towards the service sector. Disposable incomes rose in the cities and government looked to reduce the cost of welfare provision and particularly public housing, which expanded greatly between the 1940s and 1970s. It sought, essentially, to channel rising income into private housing, ending its commitment to mass public housing in 1980. A richer population should be housing itself and not relying on state welfare: this was the essential message of Thatcherism. This focus on owner-occupation chimed well with economic restructuring and the UK's new role as a financial centre in the maturing global economy. Private mortgage lending was deregulated, providing the finance needed to privatise public housing and drive the broader expansion of owner-occupation (Wainwright, 2009). Within this broader national narrative, rural and urban areas took different paths.

A refocusing of production in cities was matched by the increasing consumption of rural areas, as places of amenity and investment opportunity. Low rural wages resulted in depressed house prices (Coppock, 1977). Higher urban wages alongside access to domestic mortgage finance started to lift house-prices onto a higher track, reinforcing interest in rural property markets from the 1970s onwards (ibid.). All of this, combined with new levels of accessibility (the expansion and extension of the motorway network from the 1960s onwards), triggered rural restructuring towards services, especially tourism, and a broader consumption of the countryside (reflected in counter-urbanisation and the arrival, in significant numbers of salaried 'urban, middle class newcomers' who continued to 'work in towns', Newby, 1979: 165). That restructuring, which prized amenity above primary production, led to a new rural politics rooted in private property interests and expressed through more restrictive land-use planning.

Rural planning had already been restrictive - limiting most development to service centres - before the market intrusions of the 1970s. Strategic 'Structure Planning' in the 1960s, for instance, had defined settlement hierarchies and directed development to selected locations (Cloke, 1979; Sillince, 1986), protecting the open countryside from sporadic development. But new forms of market entry, and property interest, from the 1970 s onwards, accentuated this tendency towards protection. A prioritisation of protection over development has played its part in limiting the rural housing supply, sustaining a scarcity which is attractive to mobile capital. That attraction, combined with an emphasis on protection and therefore amenity, has brought new market entrants from Shucksmith's 'more prosperous groups'. This is not a universal truth, but rather a pattern that is common enough to explain rural housing outcomes in many areas.

Saunders (1984) has argued that the property owning class is motivated to ensure the capital accumulation of its property, so will favour restricting housing supply through planning. Non owners, on the other hand, are not directly affected by price change, so will have different attitudes towards the role of the planning system in advancing or restricting supply. Rural market entrants from the 1970s brought with them a different set of priorities: protect those things - amenity and scarcity that sustain asset value. These priorities can both conform and conflict with the 'associational interests' of others (Milbourne, 2006). Those expecting to inherit property, or hoping to be assisted by family to access it, may share the priorities of existing owners. But renters lacking family support, and therefore with a different interest in property and market position, look to planning to facilitate rather than curb development. Planning, in this situation, becomes an expression of dominant associational interest - often restricting new housing supply or limiting it to service centres, driving a social reconfiguration (aka gentrification) elsewhere.

c) Lowest level - description and policy 'realism' 
At the lowest level, this mismatched competition between different property classes becomes the cause celebre of local authorities: something must be done to alter the dynamic. But local authorities can only intervene at the local level, and not upstream where the die has been cast. Over the last 30 years, increased attention has been paid to the lowest level: the detail of local market dynamics (divorced from any explanation of up-stream drivers) and the question of what can be done to engineer different outcomes. This reflects a general tendency in the study of rural housing, with researchers being 'content to provide more descriptive and policy-relevant accounts of housing and homelessness in rural areas' (Milbourne, 2006: 441). Emphasis is placed on corrective intervention rather than systemic change, on policy realism rather than aspiration.

\section{Part II: Lowest-level intervention and its consequences}

This section explores lowest-level market intervention and its consequences, drawing firstly on theory, secondly on past experience in the Lake District, and finally on the authors' own research in St Ives in Cornwall. Work in St Ives examined (1) the pressures that foregrounded recent intervention, (2) the logic of that intervention, (3) its gestation in local discourse, (4) signs of early impact, and (5) expectations concerning market segmentation, introduced below. These observations are elaborated in order to illuminate the power of lowest-level intervention relative to the property interests that frame local housing outcomes.

Two types of lowest-level intervention are possible: supply non-market housing alternatives or intervene to restrict the occupancy of market housing to defined 'local groups'. Public housing delivery has dwindled over the last 40 years. In addition it is difficult for local authorities to bring land into public ownership, with Land Compensation measures failing to challenge private property rights (see Lyons, 2014). In the absence of new public housing, authorities have tried to restrict the occupancy of new private housing in the absence of new public housing.

\section{a) Theorising impacts}

Housing outcomes - patterns of access and levels of affordability - are underpinned by the movement of mobile capital into (a necessarily finite supply of) private residential property. But what happens when a planning authority - or similar regulatory body - acts to restrict that movement? Development planning can determine the location and form of development and, to some extent, the mix of tenures. In some circumstances, it can also restrict access to newly built homes through the use of legal agreements - conditions on the granting of planning permission. But it cannot retrospectively apply similar restrictions to the use of second-hand property. Motivated by the goals of access and affordability, the aim of these occupancy restrictions is firstly to give advantage to one domestic property class (lower income and lower wealth groups) over another (more prosperous groups moving into an area) and secondly to decelerate the flow of mobile capital into a market area, thus slowing the rate of house price inflation. However, because they act on a segmented market (split between new and second-hand residential property), they tend to focus rather than decelerate the inward flow of mobile capital, which will have implications for both development activity and price inflation.

These implications are shown in Figure 1, which describes the segmentation of the housing market into its new build and second-hand components. A restriction imposed on the occupancy of new housing in an otherwise 'free' market will cause the new build demand curve (showing demand from both local purchasers and market entrants) to be replaced by local demand alone. The displaced external demand from market entrants joins the second-hand market. ' $D$ ' is pushed down on the left and up on the right. Where local amenity value underpins life-style and investment buying the supply curve of second-hand housing is relatively price-inelastic. This produces, on the right, a large second- 
hand excess demand and a steep price rise. In the new build segment the residual value of land under development falls, threatening some schemes as ' $\mathrm{S}$ ' adjusts downwards.

Under such restrictive planning rules new housing may still be produced if public land can be brought forward or if developers hold significant land banks and can be incentivised to keep developing for the now restricted (and lower income) 'local market'. But it is quite possible that landowners and developers will simply sit it out, waiting for a successful challenge in the Courts. Likewise, developers may direct their attention to opportunities elsewhere, causing land values outside the area of restriction to increase. Jackson and colleagues (1994) have shown that such constraints on land release will affect the type, timing and distribution of house building activity in local price adjustments.

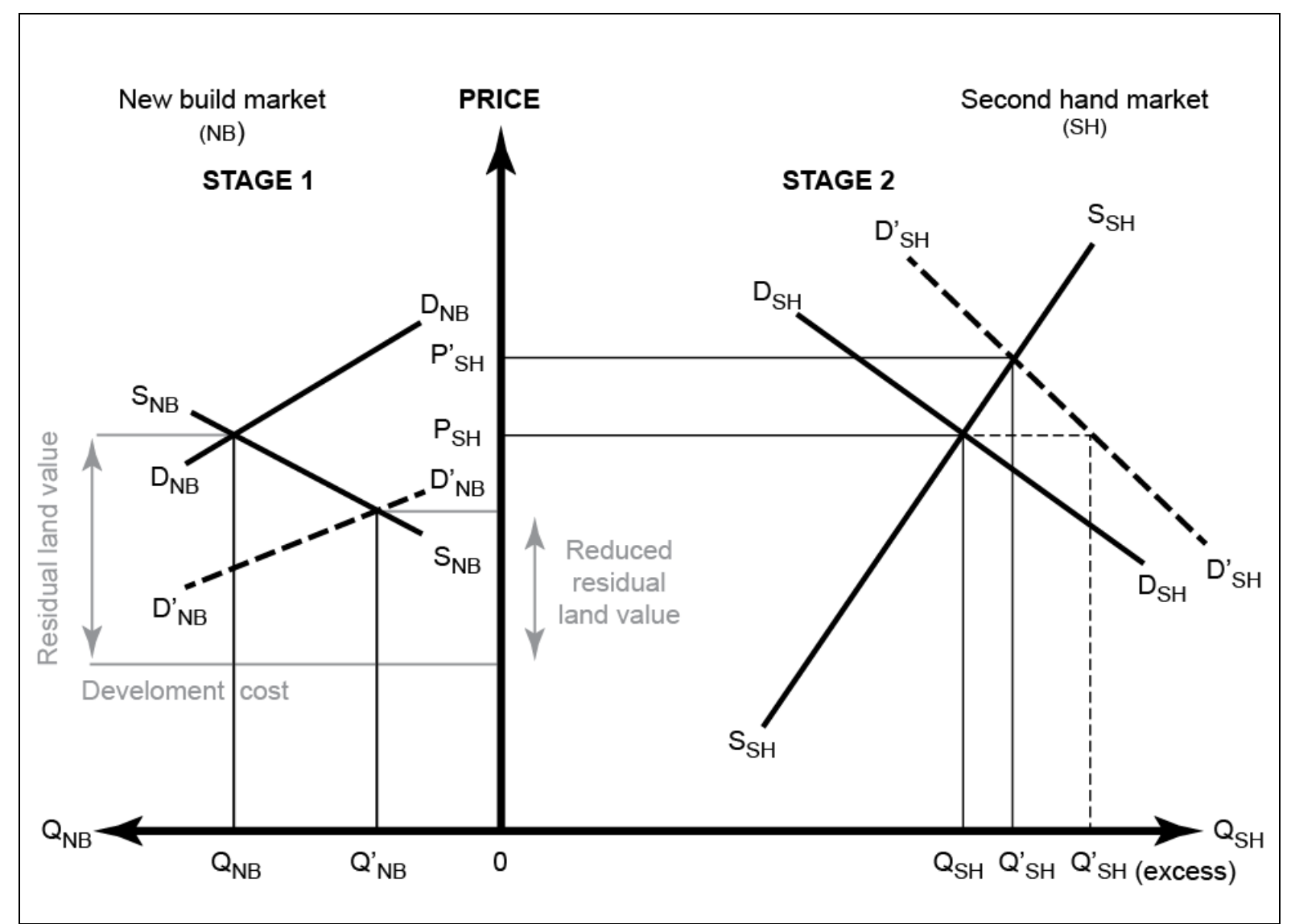

Figure 1: Segmentation of the housing market into its new build and second-hand components - and impact of market restriction affecting the new build segment (source: authors)

Because of these dynamics, local access to the second hand market may be reduced by more than any increase in access to the new build market. If the restriction remains unchanged, the longer term supply of development land may be reduced or land may eventually be supplied for non-housing use. This theory predicts a focusing of demand in the second-hand market and a loss of local development activity. These shifts push prices onto a higher track, benefiting owning rather than non-owning property classes.

\section{b) Past Evidence}

These predicted shifts in supply, demand and residual land values were observed in work by Shucksmith in the Lake District in the 1970s. Shucksmith (1981; 1990a, - and also Capstick, 1987) researched the impacts of planning restrictions to prioritise 'low income, low wealth' groups above 'more prosperous groups' looking to retire or purchase second homes. The Lake District Special 
Planning Board's 1977 draft plan sought to 'restrict completely all new development to that which can be shown to satisfy local need' and applied Section 52 (Town and Country Planning Act 1970) conditions on new development to that end. The same policy found its way into the Cumbria and Lake District Joint Structure Plan three years later (LDSP \& CCC, 1980), but broadened the definition of local need to all 'full time residents'.

The policy met with immediate criticism: the report on the Examination in Public of the Joint Structure Plan concluded that it was 'unreasonable' to use 'planning powers to attempt to ensure that houses should only be occupied by persons who are already living in the locality', adding that planning should be 'concerned with the manner of the use of land, not the identity or merits of the occupier' (DoE, 1981). Whilst the policy was eventually deleted by the Secretary of State, it remained in force - first in the Draft National Park Plan and then the Joint Structure Plan - for a full seven years until 1984. This gave Shucksmith the opportunity to study its operation and impacts (Shucksmith, 1981, 1990a) which fit with the predicted outcomes described in Figure 1.

First, more prosperous groups seeking second homes in the Lake District were undeterred by the restriction. Their preference for older village homes with 'character' meant that demand became entirely focused in that segment of the market. Second, although new build housing was now targeted at full time (i.e. 'local') residents, the supply of that housing reduced: 'partly because of the uncertainties raised by the new policy, but principally because of the greater difficulty of acquiring suitable land with planning permission' (Shucksmith, 1990a: 122). The aggregate impact was a slightly faster rate of house price inflation. While some aspiring second home buyers found the Lake District suddenly too expensive and shifted their attention elsewhere, price adjustments for second-hand and new build property were largely balanced out across the market. Excess external demand refocused entirely on second-hand property, benefiting existing owners. That same demand was removed from the new build segment, but prices there were largely unaffected owing to changes in land values, development activity and therefore reduced supply.

Shucksmith concluded that, overall, 'local people who could afford to buy new housing will have found prices roughly the same as before, once the shifts in the demand and supply schedules had worked through' (p. 123). Those unable to access home-ownership before were therefore not greatly assisted by the policy: second-hand housing was now more expensive, and new-build cost roughly the same as it did before.

c) St Ives

That finding has not deterred other local authorities from engaging in this type of lowest level intervention. The need for 'affordable housing' became a material consideration in national policy in the early 1990s (reflected in DoE Circular 7/91 (DoE, 1991) and a revised edition of Planning Policy Guidance 3: Housing (DoE, 1992) a year later). Although the intent of guidance was to establish clear routes for 'procuring' affordable housing as a planning gain - on exception sites (see Gallent and Bell, 2000) or as a percentage contribution of social rented housing in otherwise private schemes - the material consideration was interpreted by some as reopening the door on market restrictions. Responding to a surge in second home purchasing, the Pembrokeshire Coast National Park Authority introduced such a restriction in 26 so-called 'sustainable communities' in January 2002 (PCNPA, 2002). Despite the culture shift in planning noted above, the Welsh Assembly expressed some anxiety over the likely impacts of the policy: '[...] land allocated in UDPs [unitary development plans] as housing land should be available to all applicants and not allocated specifically to meet the needs of particular sections of the community' (Welsh Assembly Government, 2002: 5). Consultants were therefore appointed to look at historic precedents and advise the Park Authority (Tewdwr-Jones and Gallent, 
2003). Their report, and local criticism, led to a review of the policy following the plan's public inquiry in 2004 (Gallent and Tewdwr-Jones, 2007: 171). The policy then disappeared from later plans.

More recently, the Localism Act 2011 has empowered community groups to respond to local challenges through their own neighbourhood plans. Cornwall, with its pristine coastline and numerous fishing villages, has long been a focus of second home and retirement housing demand. Its total population rose from just over 532,000 at the 2011 Census to more than 569,000 in 2020. Cornwall's total housing stock increased from just under 259,000 dwellings in 2011 to almost 274,000 in 2017 - the last date for which unitary authority figures are available (see MHCLG, Live Table 125). In June 2015, 14,000 dwellings registered for Council Tax were listed as second homes (Cornwall Council 2015). This figures excludes homes used as holiday lets, where it is the stated intention of owners to rent those homes for at least 140 days each year. These will pay business rates, but only if an income threshold of $£ 15,000$ pa is reached. A search of commercial lettings sites suggests that there are at least 2,000 holiday lets in the county, but this will be a gross underestimate as many registered holiday lets are never rented out commercially, being registered as lets only as a means of avoiding local Council Tax. Indeed, it was reported in the Daily Mail in April 2020 that 5,000 holiday let owners in the County claimed the $£ 10,000$ government grants intended to support 'small businesses' through the COVID-19 pandemic (Daily Mail, 2020). It is probable that between $15 \%$ and $20 \%$ of homes in Cornwall are 'second homes', broadly defined.

St Ives - a town with around 12,000 residents - has a concentration of second homes: the estimate that $25 \%$ of its stock is used by seasonal residents is likely an under-estimate given the difficulty of identifying holiday lets. However, analysis by Cornwall Council (2015) shows that where the proportion of second homes in a parish exceeds $35 \%$, house prices will be $87 \%$ above the Cornish average. This falls to $46 \%$ in parishes, like St Ives, with between $20 \%$ and $30 \%$ of their stock used as second homes. The affordability ratio - between lower quartile house prices and lower quartile residence-based earnings - was 8.72 in 2019 (compared to 7.83 for England, which is inflated by London's figure of 12.77) (ONS, 2020). It is not possible to drill down into local affordability ratios, but it is likely that Cornwall's principal second home hotspots will have ratios significantly higher than the county as a whole, explaining why many younger households find themselves locked out of the market, especially as a high proportion of lower quartile earners find themselves in the seasonal 'accommodation and food retail' sector, which at $16.2 \%$ is exactly $9 \%$ points bigger than the national average. Gross weekly pay in the county, for all full time workers, is also $15 \%$ less than the average.

In May 2016, the residents of St Ives voted (in a local referendum) to adopt a Neighbourhood Development Plan (NDP) containing policy ' $\mathrm{H} 2$ ', restricting the occupancy of new built housing to 'full time residents' (St Ives Town Council, 2016).

Within 6 months of the referendum, and following the outcome of a judicial review into the inclusion of the occupancy restriction in the NDP, the current authors undertook a series of interviews with members of the NDP group, estate agents, local planning officers, development professionals and national policy bodies. A more complete discussion of findings is provided in Gallent et al (2019a). The following observations from this research reflect on the power of lowest-level intervention relative to the property interests that frame local housing outcomes.

1. The pressure to act

A survey of residents' views on a range of local issues was undertaken by St Ives Town Council in 2013. Many of those who responded $-20 \%$ of the town's population - felt that new housing development was seldom meeting the needs of full-time residents and their legitimate aspiration to purchase their 
own homes. A need for affordable housing, for purchase and rent, was reported alongside a general antipathy towards new residential development that was changing the character of the town. The quandary facing the Town Council was therefore how to square the circle of delivering more affordable homes whilst curbing the pace and quantity of development. A Housing Topic Group (HTG) was formed. It almost immediately looked at ways of restricting the occupancy of new homes, drawing inspiration (but not evidence) from the National Parks (particularly the Lake District) and other areas where there had been experiments with occupancy restrictions.

This was not simply about homes for locals, but rather about ensuring that homes should be lived in, by people already in the town or those wishing to take up residence in St Ives (hence the focus on 'full time residents': a label which may unfortunately be used interchangeably with the term 'local', which can wrongly suggest that the strength or length of connection with the town will be a factor in determining who can reside in occupancy-restricted housing). The eventual referendum suggested more support for the Policy amongst newer residents (including retired households) than those who had lived in the area for a long time: 'There was [in consultation responses] possibly more support from people who are brought up here for things like holiday lets that were going to bring an economic benefit to the area than there was from incomers and [...] there was probably a divide there' (HTG respondent). Interviews with members of the HTG and local Estate Agents suggested a divide between those who thought $\mathrm{H} 2$ would threaten economic development (and jobs) and those who thought that that policy would deliver amenity protection by decreasing the pace of new housing development. Estate Agents were unsurprisingly scathing of the policy, suggesting that it served the 'interest' of those wanting to see the value of their own property rise (their 'associational interest'). Members of the HTP rejected this view, arguing simply that something needed to be done. The policy would be an 'experiment', ensuring that homes were lived in.

\section{The logic of restriction}

$\mathrm{H} 2$ aimed to widen access to housing and also increase levels of occupancy - ensuring that the town's streets were not lightless and empty during the winter. Greater affordability was the goal of a parallel policy, $\mathrm{H} 1$, which sought the usual contribution of affordable housing in market schemes. But doubts were expressed over the way Policies $\mathrm{H} 1$ and $\mathrm{H} 2$ would operate in tandem: one of the development professionals interviewed argued that if residual land values fall (see Figure 1 ) because of the market restriction $(\mathrm{H} 2)$ then insistence that sites still deliver affordable housing contributions $(\mathrm{H} 1)$ will render development unviable. Restrictions on 'more prosperous groups' entering the market (who hitherto helped bid up land and property prices) will reduce the carrying capacity of housing sites. Those sites may therefore not come forward for development at all, or if they do they will not be able to carry affordable housing contributions. In short, the restriction on market entry seemed to create a more challenging environment in which to procure affordable housing contributions as a condition of planning permission. But the picture was more complex than this. It was also observed that 'between 60 and 70\%' of homebuyers were external market entrants. By transferring this demand to the second hand market, prices would rise just as the number of affordable homes procured through planning would inevitably shrink.

The view that development economics would fundamentally shift, to the detriment of 'low income, low wealth' households, was simply too bleak an assessment for some of those interviewed. The County Council Planning team suggested that greater emphasis could be placed on delivering new affordable housing though exceptional permissions on farm land adjacent to villages. HTG respondents defended the policy as an 'experiment' affecting only 300 remaining units in the life of the Local Plan. Even in a more restricted market, sufficient value could be captured through Section 106 agreements to support the delivery of affordable homes. In contrast, the national representative 
of landowners dubbed the policy an act of confused political appeasement. H2 spoke to different 'associational interests'. It was therefore unclear as to whether the underlying logic was one of amenity protection or wider housing access.

3. Local discourse and evidence

While the HTG 'took inspiration' from policies adopted elsewhere, it did not consider any significant assessment of long term impact. Few such assessments exist, the exceptions being studies by Shucksmith (1981; 1990a) and Capstick (1987), which are now more than three decades old. Those studies are occasionally dusted off by academic researchers but seldom see the light of day in more popular debate. But the HTG was less concerned with learning the more intricate lessons of market impact, and more interested in the political statement that could be made through widely-applied occupancy restriction. While generally aware of potential impacts on development pace, market segmentation and housing affordability, the stock defence remained the same: $\mathrm{H} 2$ would be a limited experiment, and could be cut short if such impacts materialised.

\section{Early impacts}

The view of $\mathrm{H} 2$ as a limited experiment conflicted with predictions of unintended consequences that could materialise given the upstream pressures bearing down on St Ives. These ranged from a cessation of all development to a more subtle suppression of land values, undermining delivery of non-market affordable housing. A local developer claimed that the 'double whammy' of Policy $\mathrm{H} 2$ and $\mathrm{H} 1$ had already stalled one scheme: 'landowner expectation is higher than the market will be prepared to buy that land from him at, which is to do with a lack of confidence'. Where land values (or house prices) suddenly change, vendors may be slow to check their expectations. Higher density schemes can preserve and extract greater value, but given they can also provoke negative community reaction, landowners are more likely to simply sit on land. Another concern was the possible reticence of banks to lend on homes with a 'burden on title'. HTG members rejected these concerns, pointing to the willingness of lenders to grant mortgages on occupancy-restricted properties elsewhere. But for developers, this additional source of risk was simply not needed - far better to develop elsewhere.

Interviewees tended to engage in 'futurology': forecasting, with uncertainty, how patterns of development might change. But at the beginning of 2017, two residential projects appear to have been affected by the occupancy restriction. The first, a new-build project with a gross development value of between $f 5$ and $f 6$ million had stalled because of uncertainty around the impact of $\mathrm{H} 2$ on the saleability of units (local developer). In the second, investors withdrew from a planned 'build and replace' project because of cost uncertainties on these previously-developed windfall sites (landowners' representative). These examples could point to lasting impacts on the propensity of development to come forward, with consequences throughout the supply chain, from local tradesmen engaged in the housebuilding sector to their earnings spent in the local economy. On the other hand, they could simply signal that developers and investors are 'finding their feet': getting used to new rules and trying to figure out their implications for development (local developer). Their cost and risk assessments will eventually accommodate the new policy, as regularly happens when planning rules and regulations change (see Gallent et al, 2019b).

Recent reporting on St Ives' 'second home ban' has tended to confirm the initial view of estate agents: policy $\mathrm{H} 2$ was an ill-conceived intervention that has not calmed house-prices or opened up new sale and rental opportunities for full-time residents. But that reporting tends to rely on follow-up conversations with agents, giving them an opportunity to confirm their worst fears (Financial Times, 2019). A number of newspapers have claimed that building companies are relocating their activities 
away from St Ives, driving a reduction in new build (Telegraph, 2019): but they offer no evidence for this. Some, including The Telegraph, have referenced work by Hilber (no date given) on the effects of restricting investment buying, but it is not clear whether Hilber has undertaken any analysis of the impacts of the $\mathrm{H} 2$ restriction in St Ives. It seems more probable that he is drawing on conclusions reached in work on second homes in Switzerland (Hilber and Schöni, 2018), which argued that housing investment consumption supports, through tax contribution and local spending, both the property market and a wider ecosystem of economic activity. The housing market peaked in 2017 and since then, the effects of the St Ives intervention have been obfuscated first by Brexit uncertainty and, more recently, by the COVID-19 pandemic. More research will be needed on the impacts of the policy in the years ahead.

\section{Market segmentation}

But despite these market uncertainties and complications, we can say with some certainty that planning restrictions act on a housing market's new build segment, controlling the occupancy of new homes through the use of a planning condition. The right of existing property owners is unaffected: the planning system cannot regulate the onward sale of second-hand property to certain buyers, since that property is free of condition or covenant. This means that rather than widening housing access, planning intervention risks a decrease in development activity and refocusing market demand in the restriction-free segment of the housing market. The theory behind this was presented above (see Figure 1). One of the critics of St Ives' occupancy restriction labelled this mechanism a 'meat cleaver', brought to bear on a complex and nuanced issue and addressing a symptom rather than the underlying cause of housing inequality: who consumes housing rather than what motivates and drives that consumption. Even those who supported the action expressed concern over its limits and inability to reach the second-hand market.

Returning to a debate that has occasionally bubbled up over the last 40 years, they proposed that housing occupied seasonally and that occupied full-time should be allocated to separate 'use classes', with planning permission required (and seldom granted) for transfer to seasonal use. The planning system would thus be employed to curb second home demand in a more fundamental way. This proposal periodically sees the light of day, being advanced by backbench MPs representing pressured rural areas in the 1980s and 1990s (Gallent et al, 2005: 168). On one hand such moves are considered a fundamental attack on 'property rights', on the other, a reasonable means of distributing the housing resource in a more equitable way. In the 1990s, the UK Conservatives called such proposals 'spiteful and impractical' (ibid) - a view repeated more recently: '[...] owning property is a human right and a fundamental British liberty [...] trying to control private ownership via the planning system will require intrusive inspectors to monitor the usage of every home and state surveillance of every property' (Planning Advisor Service, 2015). We would agree that such downstream interventions are problematic, but given that governments have struggled to extend this 'human right' (not just to 'own property' but also to a stable and decent home) as investors - including second home investors in St Ives - have consumed ever greater quantities, there is a case for more fundamental upstream action, which will not depend on intrusive local surveillance.

\section{Part III: Levelling the playing field}

Given the challenges posed by lowest-level intervention (outlined in part II), and the reality of 'structural determinants' to local housing dynamics (outlined in part I), how might this uneven planning field be levelled? Two areas have recently drawn the spotlight: tax reforms that change investor behaviour and patterns of consumption; and land reforms that might create opportunities for new forms of property ownership, including community and collective tenure. 


\section{a) $\operatorname{Tax}$}

Upstream of local outcomes, the consumption of private housing in the UK is shaped by the tax treatment of this asset. Housing for sale is consumed for both the services it delivers (its utility) and for the investment it represents (its asset value), repaid through imputed rent and cash return on capitalisation. Both homebuyers and governments globally have come to view housing as an asset: one that delivers personal financial security over time, as residential mortgages are paid off (and net imputed rent grows, leaving households with greater disposable income for consumption and eventually for retirement) and also public spending advantages, as state welfare is substituted with asset-based welfare (Rossi, 2017). Since the Second World War, and even during Council Housing's 'golden age' (i.e. the period of sustained building between 1947 and 1979), successive governments have been committed to increasing the level of home ownership and reducing fiscal support for public housing (see Stirling, 2019). There is a general misconception, promoted by those on the political right, that private housing consumption comes at no cost to government (and society more generally) and that public housing is, in contrast, a significant drain on public resources. But in order to support private housing consumption, government abolished 'Schedule A' income tax in 1963 - a tax on the 'benefit in kind', or imputed rent - that homeowners enjoy by owning rather than renting a home. Two decades later, mortgage interest relief at source (MIRAS) delivered another massive tax boost for home owners (allowing them to claim income tax relief against mortgage interest), which lasted until 2000. Shortly afterwards, the Financial Services Act (1986) opened up the UK banking sector to global investors (Wainwright, 2009: 377). The combined result of these moves was to make homeownership more tax efficient before driving up prices by super-charging domestic lending: creating a credit-house price feedback loop (Ryan-Collins, 2019) that has made housing increasingly unaffordable to many households. The under-taxing of housing includes: no capital gains tax (CGT) on primary residences (the un-earnt increment arising from price inflation is entirely tax free); capital gains on secondary residences charged at $\mathbf{2 7 \%}$ (or $19 \%$ for a home owned by a limited company for the purpose of private letting) rather than the owner's higher rate (e.g. $40 \%$ or $45 \%$ ); a range of tax reliefs for the private letting of 'investment properties'; and a Council Tax liability (linked to an outdated valuation of property values) that is a hybrid local service charge and progressive property tax, with the latter set at a startlingly low rate for high value property. Also, in relation to Council Tax, that liability falls to tenants when a property is let. Private housing has become a tax efficient asset for owner occupiers (encouraged to trade up to bigger homes in order to enlarge the capacity of their 'savings pot' although Stamp Duty Land Tax (SDLT) acts as a brake on this - see below), for landlords (with CGT on investment property set lower than their usual PAYE (pay as you earn) rate and the annual tax liability paid for by someone else), as well as for banks, for whom housing is 'high quality collateral' (Aalbers 2017) to be lent against, creating debt that can then be securitised, invested in, and traded.

Housing consumption has thereby become a focus for the UK's economy, with governments viewing house price inflation as good inflation - a measure of economic growth and success. For that reason, all political parties have tended to steer clear of interfering with the housing market at this macro level, avoiding measures that could impact on house prices and linked financial services. But it is this centrality of housing to the national economy, and the tax treatment of this asset, which generates great appetite for its consumption and produces the spectrum of impacts that are today branded the 'housing crisis', not only in the UK but around the world (Rolnik, 2013).

This deepening crisis, marked by gross inter-generational wealth inequalities (Resolution Foundation, 2018), has resulted in some adjustments. Government has added a transaction tax (SDLT) surcharge on the purchase of second homes and reined-in some of the tax reliefs for private landlords. Rules on CGT liability will be adjusted from April 2020, removing a discount for letting property rather than 
leaving it empty (to benefit solely from capital appreciation). Alongside Brexit uncertainty this has caused the housing market to stutter. Prices were flat in many parts of the UK during 2019 (and have remained flat during the COVID-19 pandemic, although the true trajectory of prices will only become apparent as transaction volumes increase, or fall, once the pandemic has subsided). This has prompted an important debate about tax: should government go further or should it step back from the brink, protecting and reinstating traditional supports for the housing market? Should the objective now be to re-establish a reasonable link between earnings and house prices (one eroded since at least the Financial Services Act 1986) or should it be to promote their upward trajectory, supporting consumer confidence and the financial services that rely on the UK's asset sheet growth?

The costs of the latter include the sorts of market distortions seen in places like St Ives, where mobile capital drives up house prices and the link with local earnings is lost. On the other hand, housing occupies centre stage in the economic life of the country, making politicians understandably wary of sudden shifts. Despite committing to ending the 'unfairness that sees income from wealth taxed at lower rates than income from work' (Labour Party, 2019: 30), the Labour Party's 2019 General Election manifesto primarily targeted income tax (on workplace earnings) rather than property tax (on unearnt wealth) as a source of additional public revenue. The commitment to end 'unfairness' (ibid, 30) in fact referred to the application of personal tax rates to CGT liability on second homes and investment property rather than a resurrection of 'Schedule $A$ ' income tax (that would see owneroccupiers face a tax on rising asset value, attributed to improvements in local services, including schools, scarcity of new housing supply, and credit supply). The object of taxation - wealth and assets versus earnings through payroll - is a recurrent theme in tax literature, with those authors prioritising 'redistributive justice' over productive efficiency (i.e. limiting fiscal drag on the productive economy) always keen to see assets and asset accumulation (and transfer) taxed at an equivalent rate to workplace earnings (Diamond and Mirrlees, 1971). The Mirrlees Review for the Institute for Fiscal Studies looked at exactly this issue, recommending the equalisation of personal tax rates on income from all sources (including capital gains) and the implementation of a 'lifetime wealth transfer tax' in place of an 'ineffective inheritance tax' that captures only 'some assets transferred at or near death' (Mirrlees et al, 2011: 479).

If at some point in the future a UK government decides to implement upstream solutions to the inequality and access concerns witnessed in many rural areas, it could do the following: charge CGT on primary residences (see Barker, 2014; 2019), causing a slowing of house price rises and managed deflation; increase capital gains on second homes to match an owner's PAYE rate (Mirrlees et al, 2011; Monbiot et al, 2019 - and committed to in the Labour Party's 2019 manifesto); and reform Council Tax, increasing liability for higher value property (Dorling, 2014) and transferring liability onto owners (Monbiot et al, 2019). Another possibility would be to abolish residential SDLT and make it part of the CGT liability. This could aid market entry and market mobility for lower income groups who are not first time buyers and do no enjoy SDLT exemption. Merging SDLT with CGT would transfer the liability from buyers to vendors who, for example, could pay SDLT on a \% of the price they paid for a property and the CGT as a \% of the uplift, less retained reliefs. The objective of these changes would be to firstly make housing more affordable overall, and secondly promote the needs of those needing a home to live in over those wanting to invest. The theory is that the 'market' could be made to cater for a wider spectrum of needs if there were fewer investors in that market, though such a big upstream shift would generate a range of economic knock-on effects.

b) Land

These measures could deliver a fairer and more optimised form of asset-based welfare with more people benefitting from home-ownership, and the reduced 'gross development value' of housing land 
creating new options for its use. But private housing use will likely remain a highly profitable use in many instances, sustaining a key barrier to alternate housing models where land remains in private ownership. There is therefore a case for a separate land reform which supports those models, for example through community-led development and community ownership of land.

The average price paid for an acre of farmland in England at the beginning of 2019 was just under $£ 17,300$ per hectare (Knight Frank, 2019). In contrast, land with planning permission for residential use ranged in value, in 2017, from $£ 370,000$ per hectare in Bassetlaw to $£ 180,600,000$ in Kensington and Chelsea (MHCLG, 2018). The average price of 'housing land' in the North East (well away from the distorting effect of London prices) was just over $f 1$ million -60 times the average price of farmland in England. This underlying value of land is reflected in the cost of housing. Rural planning exceptions - where affordable housing is permitted on farmland adjacent to a village - reduce the cost of housing by negotiating a price for land that exceeds (current use) agricultural value but is many times lower than (intended use) housing value. But more generally, necessary planning restriction corrals value into developable land, with that value ultimately being extracted by private landowners when land is developed or sold on with planning permission. Private land ownership concentrates 'value capture' in private hands, but that value is created by public investments: '[...] roads are made, streets are made, railway services are improved, electric light turns night into day, electric trams glide swiftly to and fro, water is brought from reservoirs a hundred miles off in the mountains - and all the while the landlord sits still [...] To not one of those improvements does the land monopolist contribute, and yet by every one of them the value of his land is sensibly enhanced' (Churchill, 1909).

This reality underpins the case for land reform - approaches to purchase and compensation that bring land into either public or community ownership, resulting in a fairer distribution of value, reflecting the state's (and society's) role in creating that value.

The emphasis in England has been on bringing land into public ownership. There is a long history of trying to effectively tax 'betterment' (the uplift in land value arising from development permission). Failure to advance a national system has resulted in a system of 'planning gain', locally negotiated as a condition of planning permission. That system leaves power with private owners, who can choose to develop or not develop land depending on private assessments of profitability. Where housing is needed, compulsory purchase order (CPO) powers exist to bring land into public ownership, but there are problems with the current system (Lyons 2014). CPO is controversial and seen by some as an affront to 'natural' private property rights. Many local authorities have little experience of their effective use, and they are rooted in outdated legislation from the mid-nineteenth century (p. 69). But one problem, more than any other, has limited the use of CPO: although the Land Compensation Act 1961 required that the hope value attributable to the prospect of development [...] be disregarded, allowing for land to be acquired at close to current use value, in many cases agricultural value' (p.70), subsequent case law and precedent has led to the conclusion that future permission for an alternate use should be factored into CPO valuation. Local authorities obliged to pay intended rather than current use value for land therefore transfer the value created by public investments back to the private owner. This means that the sort of public land assembly that produced New Towns after the Second World War (and large scale public housing programmes of the sort proposed in the Labour Party's 2019 Manifesto) are not possible without changes to compensation rules. Such changes appeared possible in 2019: 'Labour will set up a new English Sovereign Land Trust, with powers to buy land more cheaply for low-cost housing' (Labour Party, 2019: 78). A new Land Compensation Act would be needed, linking compensation (payable to private landowners) more closely to current use value. Drawing on Wei Yang \& Partners and Freeman (2014), the Lyons Housing Review (which was commissioned by the Labour Party) argued that 'CPO powers should be based 
upon current use value plus a generous premium rather than the future use value once development is complete' (Lyons, 2014: 71). Yang and Freeman proposed 'tapered premiums', with landowners receiving 300 to 400 per cent of current use value: so 3 or 4 times the price of farmland (far less than current price ratios). In instances where local authorities were intending to sell land for private development on larger sites brought into public ownership, this system of value capture would support public investment in enabling infrastructure. For smaller rural sites adjacent to villages and small towns, the result would be a more systematic form of 'exceptions'. Presumably, an English Sovereign Land Trust would need to demonstrate a need for 'low cost housing' before embarking on such purchases. This would be easy to do in places such as the Lake District or St Ives.

The transfer of land into public ownership could be a precursor to community control and use, with land gifted to community trusts or housing associations. Community land trusts (CLTs) provide a vehicle for delivering affordable housing and thereafter controlling its use. These trusts are often viewed as an outlet for community frustration and ambition - an opportunity to take control of local circumstances and, through cooperation, deliver forms of housing suited to a community's needs (Hudson et al, 2019). Community-based action of this types commands support across the political spectrum, aligning with the left's ethic of mutualism and the right's predilection towards self-help. In the US, land trusts have a strong association with the civil rights movement (Monbiot et al, 2019). In the UK, the idea of land being held in trust - for the benefit of 'low income, low wealth' groups provided part of the template for Ebenezer Howard's Garden Cities. The number of new CLTs in the UK rose from 120 in 2017 to 250 in 2019 (Hilditch, 2019), but growth in this sector is inhibited by land availability. Mechanisms for directly bringing land into community ownership are limited. In England and Wales, the Localism Act 2011 introduced a 'Community Right to Bid' for assets of community value, which must nevertheless be purchased at market value (and only at reduced cost where a landowner is motivated to sell to the community). Similarly, the Self-Build and Custom Housebuilding Act 2015 together with the Housing and Planning Act 2016 place a statutory duty on local authorities to take positive action in support of community and individual self-build. This can mean the release of public land for such projects or including expressed demand for self-build (reported in 'self-build registers') in calculations of objectively assessed need for housing, resulting in enlarged land allocations. Such measures may impact indirectly on land prices, but they do not involve any land being compulsorily brought under public or community control. This is also the case in Scotland, which has been subject to a series of land reform Acts over the last 20 years. Following devolution, the Scottish Parliament moved to abolish feudal tenure and associated payments - 'feu' duties to superior landlords. It also set up a Scottish Land Fund to assist communities with the purchase of private land. The Land Reform (Scotland) Act 2003 then created a right for rural communities, with a population of fewer than 10,000 inhabitants, to have first refusal to purchase private land coming onto the market. Crofting communities were handed the right to buy land at any time, even if the landowner did not wish to sell. More recently, the Land Reform (Scotland) Act 2016 established a 'community right to buy for sustainable development', which like the right handed to crofting communities, compels landowners to sell land to a community (or nominated third party) if that sale is judged by the Scottish Land Commission to support sustainable development.

The radical feature of Scottish Land Reform is the rebalancing of power between rural communities and private landowners. The compulsion on land owners to sell to communities will impact negatively on land prices, but communities still pay 'market value' for the land's intended use. As in England, the Scottish Parliament continues to grapple with the question of how 'to give planning authorities the ability to acquire development land at values closer to its existing use' (Scottish Land Commission, 2018; see also Adams, 2015 for a broader discussion of challenges). It seems inevitable that a much higher proportion of the value in developable private land, created largely through public investment, 
will only be captured for community use through radically different compensation arrangements. An alternate approach to land taxation that discourages owners from hanging onto land allocated for development in local plans (Ryan-Collins et al, 2017), through a recurrent land tax, might also incentivise sale or gifting to communities for local housing projects. But such an approach is more suited to growth areas than small village locations, where it might unleash speculative development and threaten local amenity.

\section{Conclusions}

Rural housing outcomes in England and elsewhere are structured by the protections afforded the use of private property and land, the 'freedoms' of the market, and the consequent movement of mobile capital into profitable investment. Given that housing is an undertaxed and under-supplied asset, it makes sense for capital to switch into residential property, to capture land rent in its revenue and capitalised forms. At a household level, advantage and disadvantage in rural housing markets is enjoyed or endured according to membership of a particular domestic property class: either one characterised by 'low income, low wealth' or by greater prosperity. The inter-generational transfer of wealth, in groups with family histories of property ownership, is important in bestowing advantage. In this paper, we have argued that private property and the tax treatment of housing are key 'upstream' structures determining downstream outcomes, of the type seen in many rural areas but illustrated here using Shucksmith's example of the English Lake District and our own research in the Cornish town of St Ives.

There are political and economic impediments to adjusting or reforming these structures. Private property is viewed as a natural state and a fundamental right that cannot be infringed upon. And because of housing's central position in the UK economy, reform of the tax system is often discussed but seldom implemented in anything but a minor way. We are not, however, alone in making the case for broader tax and land reform, comprising taxes on 'inessential' housing consumption and the release of land for community use at below market cost, enabled through compulsory purchase arrangements which compensate landowners at closer to current use value. These reforms would empower communities to take those actions, including the development of housing for restricted purchase and below-market rent, needed to address the gross housing inequalities found across the UK and elsewhere. Our focus in this paper has been on rural areas and rural housing outcomes, illustrated through research in English amenity areas. In the absence of upstream action, residents' groups and local authorities must find ways to increase the affordability and accessibility of local housing, but lowest-level interventions that seek to distribute existing housing in new ways inevitably interact with broader structures, of production and consumption, to generate unintended consequences. Arguably, a sustained programme of public housebuilding in rural areas, and elsewhere, would go a long way towards remedying housing stresses - and there is a very strong case for such a programme, probably linked to either the granting of exceptional planning permission on agricultural land in the smallest village locations or the zoning of that land solely for public housebuilding. But our focus has rather been with the distribution of housing wealth and with tax and land reforms that have the potential to allow more people to access ownership and enjoy the longterm benefits of that tenure. Housing outcomes in England's rural areas reveal an acute inequality of opportunity: through a tax focus on property wealth and land reforms that promote community use above private profit, there is every chance of levelling the playing field and increasing access to a wide choice of housing tenures.

\section{Acknowledgement}


The research on which this article draws was funded by UCL Grand Challenges. We would especially like to acknowledge the longstanding support of lan Scott and James Paskins.

\section{References}

Aalbers, M. (2017) The Financialization of Housing: A Political Economy Approach, London: Routledge

Adams, D. (2015) Explaining Public Interest-Led Development, Urban land Reform Briefing Paper No.4, University of Glasgow: Glasgow

Ambrose, P. (1974) The Quiet Revolution: Social Change in a Sussex village, 1871-1971, Sussex University Press.

Argent, N., Tonts, M., Jones, R., and Holmes, J. (2014) The amenity principle, internal migration, and rural development in Australia, in Annals of the Association of American Geographers, 104, 2, pp. 305-318.

Ball, M. (1986) Housing analysis: Time for a theoretical refocus? In Housing studies, 1, 3, pp. 147-166.

Barker, K. (2014) Housing: Where's the Plan? London Publishing Partnership: London

Barker, K. (2019) Redesigning Housing Policy, in National Institute Economic Review, 250, 1, R69-R74.

Bowie, D. (2017) Radical Solutions to the Housing Supply Crisis, Bristol: Policy Press

Capstick, M. (1987) Housing Dilemmas in the Lake District, University of Lancaster: Centre for North West Regional Studies

Churchill, W. (1909) The Mother of all Monopolies - From a Speech Delivered at King's Theatre in Edinburgh on 17 July 1909.

Cloke, P. J. (1979) Key settlements in rural area, London: Methuen.

Coppock, J.T. (1977) Second Homes: Curse or Blessing? Pergamon: Oxford

Cornwall Council (2015) Second and Holiday Homes, Cornwall Council: Truro.

Daily Mail (2020) Holiday home owners have claimed $£ 50$ million of taxpayers' cash intended to support small businesses in Cornwall survive through the coronavirus lockdown, Daily Mail, 27 April 2020

Department of the Environment (1991) Circular 7/91: Planning and Affordable Housing, DoE: London

Department of the Environment (1992) Planning Policy Guidance Note 3: Housing, DoE: London

Diamond, P., Mirrlees, J. (1971) Optimal Taxation and Public Production II: Tax Rules, in The American Economic Review, 61, pp. 261-278

Dorling, D. (2014) All That Is Solid: How The Great Housing Disaster Defines Our Times, and What We Can Do About It, Penguin: Harmondsworth

Dunn, M., Rawson, M., \& Rogers, A. (1981) Rural Housing: Competition and Choice, London: Allen \& Unwin.

Financial Times (2019) Has the St Ives second home ban backfired, Financial Times, 13 September 2019

Gallent, N. (2019a) Whose Housing Crisis? Assets and Homes in a Changing Economy, Policy Press: London.

Gallent, N. (2019b) Situating Rural Areas in Contemporary Housing Access Debates in England-A Comment, in Planning Practice \& Research, 1-9.

Gallent, N., \& Bell, P. (2000) Planning exceptions in rural England: past, present and future, Planning Practice and Research, 15, 4, pp. 375-384.

Gallent, N., Hamiduddin, I., Stirling, P., \& Kelsey, J. (2019a) Prioritising local housing needs through land-use planning in rural areas: Political theatre or amenity protection? Journal of Rural Studies, 66, pp. 11-20.

Gallent, N., de Magalhaes, C., Freire Trigo, S., Scanlon, K. and Whitehead, C. (2019b) Can 'permission in principle' for new housing in England increase certainty, reduce 'planning risk', and accelerate housing supply? In Planning Theory and Practice, forthcoming.

Gallent, N., Tewdwr-Jones, M. \& Mace, A. (2005) Second Homes: European Perspectives and UK Policies, Ashgate: Aldershot

Gallent, N., Tewdwr-Jones, M. and Shucksmith, M. (Eds.) (2003) Housing in the European Countryside, Routledge: London

Gallent, N. and Tewdwr-Jones, M. (2007) Decent Homes for All: Planning's Evolving Role in Housing Provision, Routledge: London

Hilber, C. and Schöni, O. (2018) The economic impacts of constraining second home investments, London School of Economics: London

Hilditch, M. (2019) The local heroes: what is the future for community land trusts? Inside Housing, available at: https://www.insidehousing.co.uk/insight/insight/the-local-heroes-what-is-the-future-for-community-landtrusts-60307 
Hudson, J., Scanlon, K., Fernandez-Arrigoitia, M. and Saeed, S. (2019) The Wider Benefits of Cohousing: The Case of Bridport, LSE: London.

Jackson, A., Monk, S., Royce, C. and Dunn, J. (1994) The Relationship between Land Supply and Housing Production, Joseph Rowntree Foundation: York.

Knight Frank (2019) Farmland Index Q1 2019, Knight Frank: London

Labour Party, The (2019) It's time for real change: The Labour Party Manifesto 2019, The Labour Party: London

Lake District Special Planning Board \& Cumbria County Council (1980) Cumbria and Lake District Joint Structure Plan - Written Statement, LDSPB \&CCC: Kendal

Lake District Special Planning Board (1977) Draft National Park Plan, LDSPB: Kendal

Lawton, R. (1973) Rural depopulation in nineteenth century England, in Mills, D. (Ed) English Rural Communities, Palgrave, London, pp. 195-219

Lekies, K. S., Matarrita-Cascante, D., Schewe, R., and Winkler, R. (2015) Amenity migration in the new global economy: Current issues and research priorities, in Society \& Natural Resources, 28, 10,pp. 1144-1151.

Lyons, M. (2014) The Lyons Housing Review: Mobilising across the Nation to Build the Homes Our Children Need, accessed 20 November 2019 at: https://www.policyforum.labour.org.uk/uploads/editor/files/The Lyons Housing Review 2.pdf

Marcouiller, D., Lapping, M. and Faruseth, O. (2011) Rural housing, exurbanization, and amenity-driven development: contrasting the 'haves' and the 'have nots', Ashgate: Farnham

Martin, E.W. (1962) The Book of the Village, Phoenix House: London.

MHCLG (2018) Land Value Estimates, accessed 22 November 2019 at: https://www.gov.uk/government/publications/land-value-estimates-for-policy-appraisal-2017

Milbourne, P. (2006) Rural housing and homelessness, in Cloke, P., Marsden, T. \& Mooney, P. (Eds.) Handbook of Rural Studies, Sage: London, pp. 427-444.

Mirrlees, J., Adam, S., Besley, T., Blundell, R., Bond, S., Chote, R., Gammie, M., Johnson, P., Myles, G., and Poterba, J. (2011) Tax by Design: The Final Report of the Mirrlees Review, Institute for Fiscal Studies: London

Monbiot, G., Grey, R., Kenny, T., Macfarlane, L., Powell-Smith, A., Shrubsole, G. \& Stratford, B. (2019) Land for the Many: Changing the way our fundamental asset is used, owned and governed, Labour Party: London

Mulheirn, I. (2019) Tackling the UK Housing Crisis: Is Supply the Answer? UK Collaborative Centre for Housing Evidence: London

Newby, H. (1979) Green and Pleasant Land? Social Change in Rural England, Hutchinson: London

ONS (2020) House price to residence based earnings ratio, Office for National Statistics: London

Pahl, R.E. (1966) The rural-urban continuum in Sociologia Ruralis, 6, 3, pp.299-329.

Pahl, R. E. (1975) Whose City? And Further Essays on Urban Society, Penguin Books: London

Paris, C. (2010) Affluence, Mobility and Second Home Ownership. Routledge: London

Pembrokeshire County Council \& Pembrokeshire Coast National Park Authority (2002) Joint Unitary Development Plan Deposit (2000-2016), PCNPA: Haverford West

Planning Advisory Service (2015) Advice from Planning Advisory Service in regard to second homes. Available at: https://www.dorsetforyou.gov.uk/media/207891/Planning-Advisory-Service-advice-on-secondhomes/pdf/Second_Homes_Advice.pdf

Resolution Foundation (2018) A New Generational Contract: The Final Report of the Intergenerational Commission, Resolution Foundation: London

Rolnik, R. (2013) Late neoliberalism: The financialization of homeownership and housing rights, in International Journal of Urban and Regional Research, 37, pp. 1058-66

Rossi, U. (2017) Cities in Global Capitalism, Cambridge: Polity Press

Ryan-Collins, J. (2019) Breaking the housing-finance cycle: Macroeconomic policy reforms for more affordable homes, in Environment and Planning A: Economy and Space, online first.

Ryan-Collins, J., Lloyd, T. \& Macfarlane, L. (2017) Rethinking the Economics of Land and Housing, Zed Books: London

Satsangi, M., Gallent, N. \& Bevan, M. (2010) The Rural Housing Question: Communities and Planning in the British Countryside, Bristol: Policy Press

Saunders, P. (1978) Domestic property and social class, in International Journal of Urban and Regional Research, 2, 1-3, pp. 233-251 
Saunders, P. (1984) Beyond housing classes: the sociological significance of private property rights in the means of consumption, in International Journal of Urban and Regional Research, 8, pp. 202-227

Scottish Land Commission (2018) Land value capture to have a proactive role in place making, accessed 22 November 2019 at: https://landcommission.gov.scot/tag/land-value/

Shucksmith, M. (1981) No Homes for Locals? Farnborough: Gower Publishing

Shucksmith, M. (1990a) Housebuilding in Britain's Countryside, London: Routledge

Shucksmith, M. (1990b) A theoretical perspective on rural housing. Housing classes in rural Britain, in Sociologia Ruralis, 30, 2, pp. 210-229

Sillince, J. A. A. (1986) Why did Warwickshire key settlement policy change in 1982? An assessment of the political implications of cuts in rural services, in Geographical Journal, pp. 176-192.

Stirling, P. (2019) Constructing London's Housing Market: National Housing Strategy and Market Mediation, unpublished PhD thesis, London: University College London

St Ives Area Neighbourhood Plan Steering Group (SIANPSG) (2015a) St Ives Area Neighbourhood Development Plan 2015-2030, St Ives: St Ives Town Council

St Ives Neighbourhood Plan Housing Topic Group (St Ives NPHTG) Minutes of the Meeting held on 15 January 2014.

Tewdwr-Jones, M. \& Gallent, N. (2003) A socio-economic impact study of local and essential needs housing. Haverford West: Pembrokeshire Coast National Park Authority

The Telegraph (2019) St Ives second home ban backfires as construction companies leave and house prices rise, LSE study finds, The Telegraph, 31 October 2019

Tunstall, B. (2015) Relative housing space inequality in England and Wales, and its recent rapid resurgence, in International Journal of Housing Policy, 15, pp. 105-26

Wainwright, T. (2009) Laying the foundations for a crisis: Mapping the historico-geographical construction of Residential Mortgage Backed Securitization in the UK, in International Journal of Urban and Regional Research, 33, 2, pp. 372-88

Wei Yang \& Partners and Freeman, P. (2014) New Garden Cities: Visionary, Economically Viable and Popular Entry for Wolfson Economics Prize, Wei Yang \& Partners: London

Welsh Assembly Government (2002) Objections to the Joint Pembrokeshire Unitary Development Plan (to 2016), Welsh Assembly Government: Cardiff. 